\title{
Physical and biological controls on the maintenance and dissipation of a thin phytoplankton layer
}

\author{
O. M. Cheriton ${ }^{1, *}$, M. A. McManus ${ }^{2}$, M. T. Stacey $^{3}$, J. V. Steinbuck ${ }^{4}$ \\ ${ }^{1}$ Long Marine Lab, University of California Santa Cruz, 100 Shaffer Road, Santa Cruz, California 95060, USA \\ ${ }^{2}$ Department of Oceanography, University of Hawaii, Honolulu, Hawaii 96822, USA \\ ${ }^{3}$ Civil and Environment Engineering Department, University of California Berkeley, Berkeley, California 94720, USA \\ ${ }^{4}$ Department of Civil and Environmental Engineering, Stanford University, Stanford, California 94305, USA
}

\begin{abstract}
During an 8.5 h overnight study in Monterey Bay in 2005, continuous, high-resolution vertical profiles of a thin layer of phytoplankton as well as physical properties of the water were measured. The thin layer was populated by strong-swimming, vertically migrating dinoflagellates. This dataset provided a unique opportunity to apply an existing mathematical model that describes how competing convergence and divergence mechanisms contribute to the formation and structure of thin plankton layers. Compared to straining by shear, cell settling velocities, and plankton motility, vertical displacements caused by the passage of internal waves had the greatest influence on changes in layer thickness. Thus, for a model to accurately describe thin-layer dynamics in an environment with internal waves, the convergent and divergent effects of the vertical oscillations caused by internal waves must be considered.
\end{abstract}

KEY WORDS: Thin layer $\cdot$ Physical processes $\cdot$ Internal waves $\cdot$ Analytical framework $\cdot$ Monterey Bay

\section{INTRODUCTION}

Advances in sampling methods and in optical and acoustic technology over the past 2 decades have enabled observations of subsurface plankton patches with a vertical extent that is less than the $5 \mathrm{~m}$ sampling resolution usually achieved using traditional bottles and nets (Cowles et al. 1990, Donaghay et al. 1992, Holliday et al. 1998, Osborn 1998). These 'thin layers' are ubiquitous features in the coastal ocean and are found in a variety of environments (McManus et al. 2003, Cheriton et al. 2007). They can extend horizontally for several kilometers and persist in the environment for days (Rines et al. 2002). Thin layers may be composed of a wide variety of organisms such as phytoplankton, zooplankton, bacteria, viruses, larvae and marine snow; however, they may also be composed of a single species that is distinct from the populations in the surrounding water column or other thin layers (Alldredge et al. 2002, McManus et al. 2003). The concentrations of organisms within thin layers are often orders of magnitude greater than those above and below, indicating that thin layers may be regions of concentrated biological and chemical processes and interactions (McManus et al. 2008).

Over the past decade, several important findings on the relationship between thin plankton layers and the physical structure of the water column have been reported. Dekshenieks et al. (2001) found that thin phytoplankton layers in a North Pacific fjord were often associated with the pycnocline, and reported that no thin phytoplankton layers were observed in regions of the water column where the Richardson number $(R i)$ was $<0.23$. McManus et al. (2003) reported that thin layers can persist in regions where turbulence is moderate but insufficient to cause vertical mixing. During a 2002 study in Monterey Bay, California, thin layers of zooplankton were associated with regions of reduced 
current velocity, or in the layer of no motion, indicating that organisms within the thin layer may have a decreased transport rate (McManus et al. 2005). Consequently, thin layers may be important mechanisms for the retention of larvae and harmful algal bloom phytoplankton species in the coastal environment (Donaghay \& Osborn 1997, McManus et al. 2008).

Several mechanisms have been proposed to result in the formation of thin layers. First, buoyancy may cause organisms and biological material such as marine snow to settle based on density gradients (Derenbach et al. 1979, Franks 1992, Alldredge et al. 2002). Second, broad patches may be thinned by vertical shear due to current jets, internal waves, or horizontal intrusions (Kullenberg 1974, Franks 1995, Stacey et al. 2007, Ryan et al. 2008). In addition, other biological processes may play a role in thin layer formation either through in situ growth of phytoplankton, active swimming by phytoplankton and zooplankton, or differential grazing (Donaghay et al. 1992, Cowles et al. 1998, Osborn 1998, Alldredge et al. 2002, Holliday et al. 2003, McManus et al. 2003, 2005).

Franks (1995) presented a numerical model whereby along-isopycnal patches of phytoplankton can be thinned by the shear created by vertically propagating, low-frequency, near-inertial internal waves. In this model, a vertical column of passive phytoplankton undergoes horizontal velocities created by near-inertial internal waves. The shear created by these horizontal currents acts to stretch the column horizontally and thin the vertical dimension of the patch. The layers produced by this model had vertical thicknesses that were less than that of the near-inertial wave and were directly related to the vertical shear and the horizontal scale of the original phytoplankton patch.

Recently, Stacey et al. (2007) presented a mathematical framework describing how the thickness of a phytoplankton layer is affected by processes acting to thin the layer (i.e. convergence) and those acting to broaden it (i.e. divergence). In this framework, the net rate of change of layer thickness is expressed as the sum of the rate of change due to convergence processes and the rate of change due to divergence caused by turbulent diffusion (Stacey et al. 2007). The convergence processes considered include straining by shear, passive settling of phytoplankton on a density surface (i.e. buoyancy), and active swimming by phytoplankton. Here, we use the math- ematical framework devised by Stacey et al. (2007) to evaluate which of the considered convergence mechanisms had the potential to be the primary process involved in the creation and maintenance of an observed thin layer of phytoplankton over an $8.5 \mathrm{~h}$ period.

\section{MATERIALS AND METHODS}

Sampling and instrumentation. From 21:30 h on 26 Aug to 06:00 h on 27 Aug 2005, we conducted a study of thin phytoplankton layers in the northeastern region of Monterey Bay (Fig. 1). From a small research vessel anchored at this site $\left(36.9356^{\circ} \mathrm{N}, 121.9191^{\circ} \mathrm{W}\right)$, we collected high-resolution vertical profiles of physical and optical properties of the water column using a custom-built, slow-drop profiler. This profiler was outfitted with a SeaBird SBE-25 CTD, which collected measurements of temperature, salinity, and pressure at a frequency of $8 \mathrm{~Hz}$. Also included on the profiler was a Wet Labs ac-9, which measured spectral absorption and attenuation at 9 wavelengths between 412 and $715 \mathrm{~nm}$. Particulate absorption at $440 \mathrm{~nm}\left(\mathrm{a}_{\mathrm{p}} 440\right)$ is generally dominated by phytoplankton chlorophyll $a$ (chl a) absorption. Unlike measurements of chl a fluorescence, $\mathrm{a}_{\mathrm{p}} 440$ is an inherent optical property that remains stable under different oceanographic and phytoplankton concentrations (Twardowski et al. 1999). Thus, we used $a_{p} 440$ to identify fine-scale optical structure in our profiles. Buoyancy floats at the top

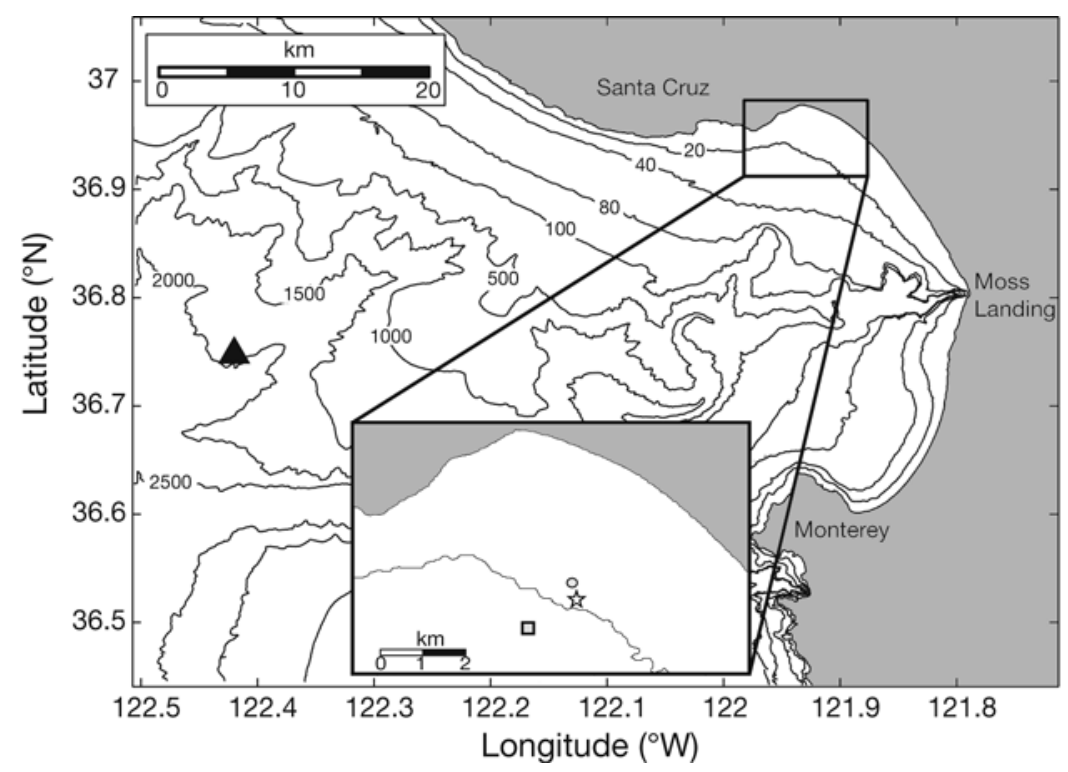

Fig. 1. Monterey Bay region with close-up view of study area (inset) showing Stn E (O), Stn W ( $\square)$, and the overnight survey site ( $(\vec{\psi})$. ( $\boldsymbol{\Delta}$ ) Location of National Data Buoy Center (NDBC) 46042 mooring. Numbers on the bathymetric contour lines denote depth in $\mathrm{m}$ 
of the profiler cage enabled the profiler to descend through the water column at an average rate of $\sim 8 \mathrm{~cm}$ $\mathrm{s}^{-1}$ and ensured that the profiler's downward motion was decoupled from the ship's movement. One vertical profile was completed roughly every 4 min for the $8.5 \mathrm{~h}$ period. Occasionally, the profiler was held at the surface for instrument checks, maintenance, and water sample collection. During this overnight survey, we collected a total of 99 profiles.

A low-pass filter was applied to the salinity data to remove anomalous spiking at the top of the pycnocline. Density was computed with the raw temperature and the smoothed salinity data using the equation of state (Pickard \& Emery 1990). Using the resulting density values, we calculated the squared Brunt-Väisälä frequency $\left(N^{2}\right)$ as:

$$
N^{2}=-\frac{g}{\rho_{o}}\left(\frac{\partial \sigma_{t}}{\partial z}\right)
$$

where $g$ is gravitational acceleration, $\rho_{o}$ is the mean density, $z$ is depth and $\sigma_{t}=(\rho(s, t 0)-1000) \mathrm{kg} \mathrm{m}^{-3}$. In the latter equation $\rho$ is density calculated from salinity (s) and temperature (t) values, with pressure $=0$ dbar (Pond \& Pickard 1983).

The Thorpe scale, $L_{\mathrm{t}}$, which provides an estimation of the overturning scale, was calculated as the root mean square displacement of each density measurement, based on the reordering of the density profile to make it gravitationally stable (see Fig. 2; Thorpe 1977). Assuming that $L_{\mathrm{t}}$ is equal to the largest overturning scale in the stratified flow (i.e. the Ozmidov scale, after Itsweire et al. 1993), we calculated the turbulent dissipation rate using:

$$
\varepsilon=L_{t}^{2} N^{3}
$$
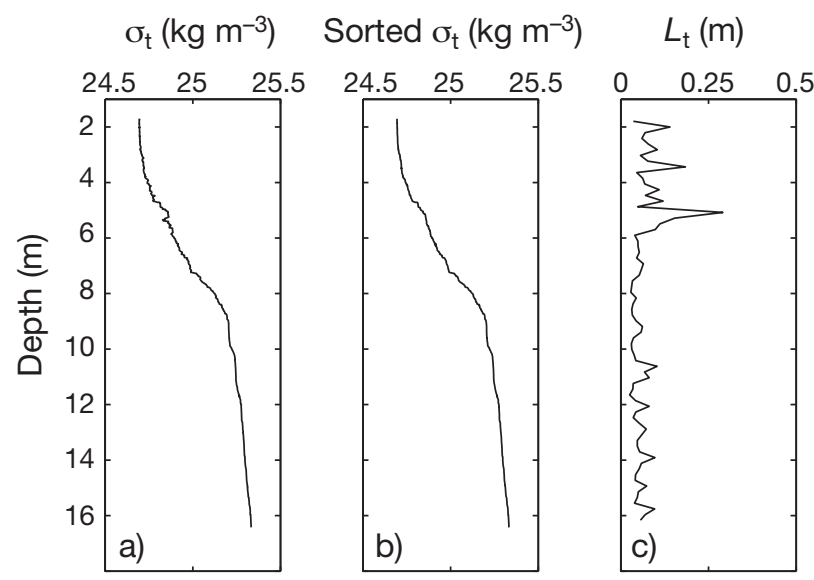

Fig. 2. Example of (a) an original $\sigma_{t}$ profile, (b) the same $\sigma_{t}$ profile sorted into a stable configuration, and (c) the resulting Thorpe scale $\left(L_{t}\right)$ profile, using a $20 \mathrm{~cm}$ bin average where $N$ is the Brunt-Väisälä frequency. Because we do not have direct measurements of turbulence during this sampling period, these values for $\varepsilon$ are approximate and based on the assumption that the Thorpe scale is equal to the Ozmidov scale (Gibson 1980, Dillon 1982).

Current velocity was measured by a vessel-mounted $600 \mathrm{kHz}$ RD Instruments Workhorse acoustic Doppler current profiler (ADCP) attached to the side of the vessel in a downward-looking mode. The current velocity data were processed by first removing all false data (measurements 'below the seafloor') and all values with an average correlation $<60 \%$ (after Storlazzi et al. 2003). We also removed velocity data that exceeded expected maximum horizontal and vertical current speeds (0.5 and $0.25 \mathrm{~m} \mathrm{~s}^{-1}$, respectively). Then, to reduce the effects of wave-induced motions of the vessel on the data, we averaged values into 2 min ensembles and twice-fit them to a 5th order polynomial. Shear was calculated after Itsweire et al. (1989) as:

$$
S=\sqrt{\left(\frac{\partial U}{\partial z}\right)^{2}+\left(\frac{\partial V}{\partial z}\right)^{2}}
$$

where $U$ and $V$ are the along- and across-shore current velocity components.

The $N^{2}$ and $S$ values were used to calculate the gradient Richardson number $(R i)$ with the formula:

$$
R i=N^{2} / S^{2}
$$

$R i$ defines the relative importance of stabilization by vertical density stratification versus destabilization by vertical shear in horizontal velocity. A threshold value of $R i=0.25$ is generally assumed to be the transition between regions of active mixing (Pinkel \& Anderson $1997 \mathrm{a}, \mathrm{b})$ and regions where the effects of buoyancy act to inhibit mixing (Pond \& Pickard 1983).

A thermistor chain composed of Onset temperature loggers was deployed in the northeastern part of Monterey Bay at $\operatorname{Stn} \mathrm{E}\left(36.9364^{\circ} \mathrm{N}, 121.9192^{\circ} \mathrm{W}\right), \sim 90 \mathrm{~m}$ from the shipboard sampling site (Fig. 1). The loggers were located at 1, 10, and $13.7 \mathrm{~m}$ above the seafloor in a $20 \mathrm{~m}$ water column and collected measurements every $30 \mathrm{~s}$. Mean water level was computed using the pressure readings from a seafloor-mounted, upward-looking $600 \mathrm{kHz}$ RDI Workhorse that was also deployed at Stn E. At Stn W $\left(36.9277^{\circ} \mathrm{N}, 121.9310^{\circ} \mathrm{W}\right), \sim 1.5 \mathrm{~km}$ from our sampling site, we deployed a Brooke Ocean Technology autonomous SeaHorse profiler. The SeaHorse was outfitted with a Sea-Bird Electronics SBE-25 CTD and a Wet Labs WETStar fluorometer and collected hourly highresolution vertical profiles of temperature, salinity, density, pressure, and chl a fluorescence.

Hourly-averaged wind velocity data were computed using wind measurements from the National Data Buoy Center (NDBC) 46042 mooring, located $\sim 42 \mathrm{~km}$ west of Moss Landing (Fig. 1). 
Thin layer identification. Thin layers of phytoplankton were identified using an algorithm based on the 4 criteria set forth by Dekshenieks et al. (2001). In order for an $\mathrm{a}_{\mathrm{p}} 440$ peak to be considered a thin layer, the feature must be $<5 \mathrm{~m}$ thick at full-width, halfmaximum, must contain at least 7 data points, and have an optical signal $3 \times$ greater than the background levels (Fig. 3). In addition, the feature must be present in at least 2 subsequent profiles. These are conservative criteria shown to accurately define the presence/ absence of thin layers in coastal environments.

The mean in-layer values of $N^{2}$, shear, and $R i$ were calculated by first defining the upper and lower depth boundaries of the thin layer in each profile. These boundaries were identified as the depths at the fullwidth, half-maximum of the $\mathrm{a}_{\mathrm{p}} 440$ profile peak (Fig. 3). The data within the boundaries were then averaged for each profile.

Settling of cells. The settling velocity of the cells, $V_{\text {settle, }}$ was calculated using the cell-specific density and a modified version of Stokes Law (after McNown \& Malaika 1950) as:

$$
v_{\text {settle }}=\frac{g D^{2}\left(\rho_{\mathrm{c}}-\rho_{\mathrm{f}}\right)}{18 \mu \phi}
$$

where $g$ is gravitational acceleration $\left(9.8 \mathrm{~m} \mathrm{~s}^{-2}\right), D$ is the nominal cell diameter, $\rho_{\mathrm{c}}$ is the cell-specific density, $\rho_{\mathrm{f}}$ is the local density of the fluid, $\mu$ is the kinematic

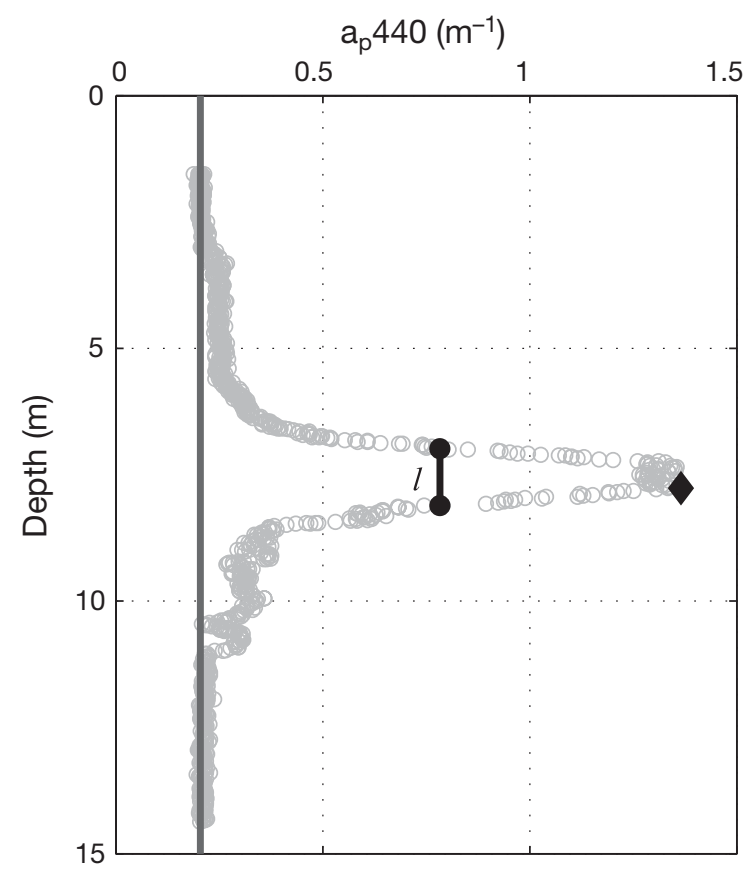

Fig. 3. Thin-layer identification criteria (after Dekshenieks et al. 2001), showing a vertical profile of $\mathrm{a}_{\mathrm{p}} 440$ (circles) collected by the slow-drop profiler at $23: 45 \mathrm{~h}$ during the overnight survey, with the peak ( ), layer thickness at full-width, halfmaximum (black line), and background level (gray line) viscosity of water $\left(\sim 10^{-3} \mathrm{~kg} \mathrm{~m}^{-1} \mathrm{~s}^{-1}\right)$, and $\phi$ is the form resistance term associated with the shape of nonspherical cells. We used $\phi=1.088 \pm 0.010$, the value associated with Akashiwo sanguinea (syn. Gymnodinium sanguineum) cells (Kamykowski et al. 1992).

Mathematical framework. Following the model put forth by Stacey et al. (2007), the net rate of change of layer thickness 1 for the observed thin layer was calculated between subsequent profiles as:

$$
\left(\frac{\partial l}{\partial t}\right)_{n e t}=\frac{\Delta l}{\Delta t}
$$

The thinning effects of shear can be analyzed for a patch of a vertical extent $l$ and at an angle with the horizontal $\theta$ (see Stacey et al. 2007). If the velocity profile is described by a constant gradient $\alpha$, then the rate by which layer thickness $l$ decreases is

$$
\left(\frac{\partial l}{\partial t}\right)_{\text {strain }}=-l \alpha \theta
$$

This relationship indicates that, as the patch gets strained towards the horizontal (i.e. $\theta$ approaching 0), the effectiveness of straining is diminished. Finally, for very small angles $(\tan \theta \sim \theta), \theta$ and $\alpha$ are related to the total time over which the patch has been strained by the relationship

$$
\alpha \theta=\frac{1}{t}
$$

which can be substituted into Eq. (7) to give:

$$
\left(\frac{\partial l}{\partial t}\right)_{\text {strain }}=-\frac{l}{t}
$$

where $t$ is the time, in $\mathrm{s}$, since the start time or original time of formation $\left(t_{0}\right)$ of the layer (Stacey et al. 2007).

The rate of change of layer thickness due to the settling velocity of the cells can be expressed as:

$$
\left(\frac{\partial I}{\partial t}\right)_{\text {settle }}=-\left(v_{\text {settle } 1}-v_{\text {settle } 2}\right)
$$

where $v_{\text {settle }}$ is the settling velocity of cells at the upper (shallower) boundary of the thin layer, and $v_{\text {settle } 2}$ is that at the bottom boundary. Both settling velocities were determined using Eq. (5) and the density measurements collected by the profiler.

The rate of layer thinning due to the motility of the organisms is given by the swimming speed of the phytoplankton, $-W_{\mathrm{s}}$ (Stacey et al. 2007). Here we assume that, once the thin layer is established, any swimming by phytoplankton will be directed towards the center of the layer, giving a rate of layer thinning of

$$
\left(\frac{\partial l}{\partial t}\right)_{m o t i l}=-2 w_{s}
$$

A comparison of the above rates of layer thinning helped us to evaluate which convergence mechanism 
— straining, settling, or motility — had the greatest influence on the formation and maintenance of the thin layer. An analysis of layer divergence and comparison of the predicted layer dynamics with the actual (net) rate of change of layer thickness enabled us to evaluate the likely role of these convergences in the observed layer dynamics.

\section{RESULTS}

\section{Survey observations}

The overnight survey was conducted between the transition from neap to spring tide during a period of moderately strong $\left(\sim 7 \mathrm{~m} \mathrm{~s}^{-1}\right)$ northwesterly winds and strong thermal stratification (Fig. 4). The survey period began at the end of ebb tide and was concluded at the end of flood tide (Fig. 5a). A thin layer of phytoplankton was observed at mid-depth from the start of sampling at 21:30 h on 26 Aug until 05:41 h on 27 Aug, when it broadened and decreased in intensity (Fig. 5b). The first few hours of sampling, from 21:30 to 00:00 h, were characterized by strong bottom currents and a relatively shallow thermocline (Fig. 5c-e). During this initial sampling period, a low-salinity layer

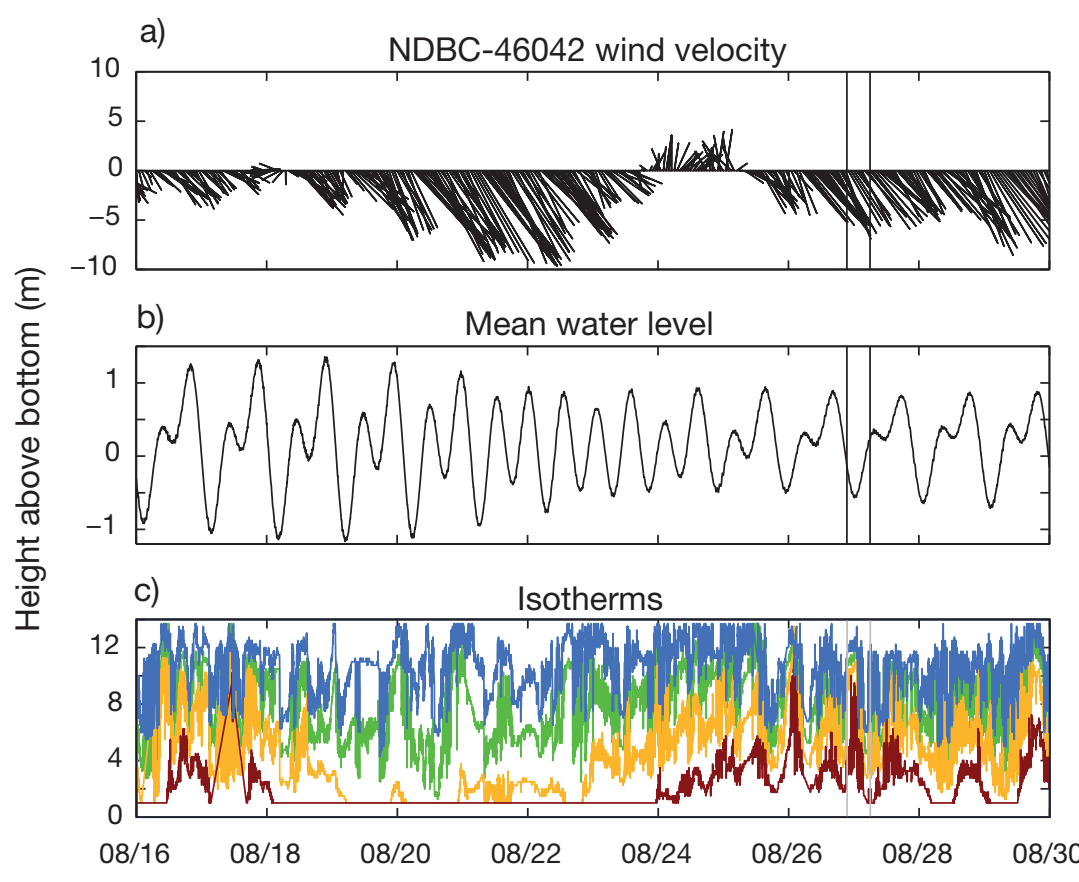

Fig. 4. Time series of mooring data from August 16 to 30, 2005. (a) Hourly averaged wind velocity $\left(\mathrm{m} \mathrm{s}^{-1}\right.$ ) from the National Data Buoy Center (NDBC) 46042 mooring, (b) water level measurements (m) from the Stn W acoustic Doppler current profiler, (c) depth of $14^{\circ} \mathrm{C}$ (blue), $13.5^{\circ} \mathrm{C}$ (green), $13.25^{\circ} \mathrm{C}$ (yellow), and $13^{\circ} \mathrm{C}$ (red) isotherms from the thermistor chain at Stn E. Vertical lines through each panel indicate the start and stop times of the profiling period with values 0.03 units below background levels was located just below the pycnocline (Fig. 5f). Data collected by an autonomous underwater vehicle deployed in Monterey Bay during this survey suggest that this low-salinity layer was an intrusion of fresher offshore waters (J. Ryan pers. comm.). The pycnocline gradually shoaled until slack tide at 00:00 h (Fig. 5g). Also during this period, bottom shears were elevated $\left(\sim 0.06 \mathrm{~s}^{-1}\right)$ and there was a sharp boundary between high $R i$ values $(>1)$ in the upper water column $(z<8 \mathrm{~m})$ and low $R i$ values $(<0.25)$ at depth (Fig. 6b,c). The deeper water column was also characterized by elevated overturning scales ( $L_{\mathrm{t}}$ up to $0.5 \mathrm{~m}$ ), while $L_{\mathrm{t}}$ values within the region of the thin layer were $<0.1 \mathrm{~m}$ (Fig. 6d). During slack tide, the $N^{2}$ values within the pycnocline region increased by an order of magnitude, and $\mathrm{a}_{\mathrm{p}} 440$ values within the thin layer increased by $>60 \%$ (Figs. 5b \& 6a).

However, as flood tide progressed, both $N^{2}$ and inlayer $\mathrm{a}_{\mathrm{p}} 440$ values gradually decreased. The pycnocline also deepened and the layer of low salinity decreased and actually became a region of slightly above-background salinity (Fig. 5f,g). In addition, there was an increase in the overturning scales in the upper water column as well as in the $\varepsilon$ values just above the thin layer, in the region of the pycnocline (Fig. 6d,e).

The later part of the flood tide period ( 03:00 to 05:30 h) was characterized by a 2-layer flow, with a southwesterly (offshore-moving) bottom current, and a northeasterly (onshore) flow in the upper part of the water column (Fig. 5c,d). The thin layer was located within the strongest region of offshore-directed flow. While shear levels were low during this period, a thin layer of moderate shear developed between these 2 oppositely moving water masses, just above the thin layer (Fig. 6b). The region of slightly elevated $R i$ values was no longer confined to just the upper water column, but expanded to almost the entire water column (Fig. 6c).

Two internal wave packets, separated by $\sim 2 \mathrm{~h}$, were observed during flood tide. Oscillations from the first internal wave packet were detected by the profiler from $\sim 01: 00$ to $03: 30 \mathrm{~h}$ (Fig. 5). Data from the nearby thermistor chain indicate that both internal wave packets had an average amplitude of $\sim 5.7 \mathrm{~m}$; however, the average period of the first packet was $\sim 9 \mathrm{~min}$, while that of the second packet was $\sim 13 \mathrm{~min}$. After the passage of the first 
a)

Mean water level (m)

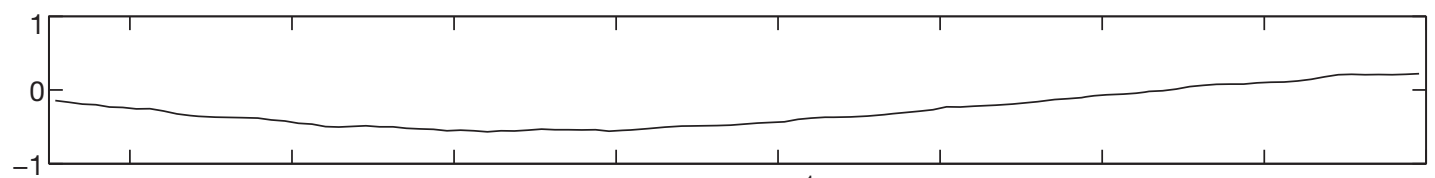

b) $\quad a_{\mathrm{p}} 440\left(\mathrm{~m}^{-1}\right)$

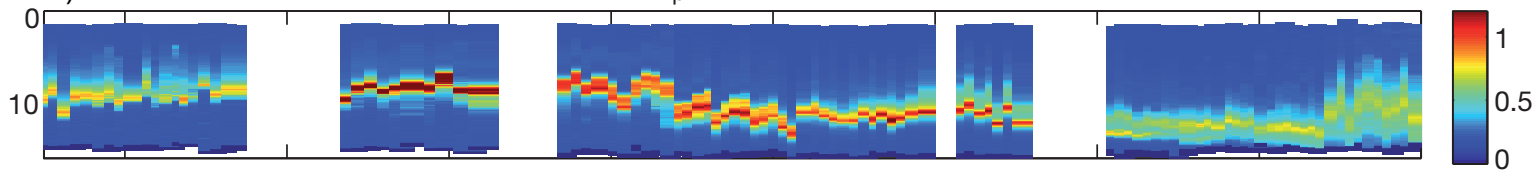

c) $U\left(\mathrm{~m} \mathrm{~s}^{-1}\right)$

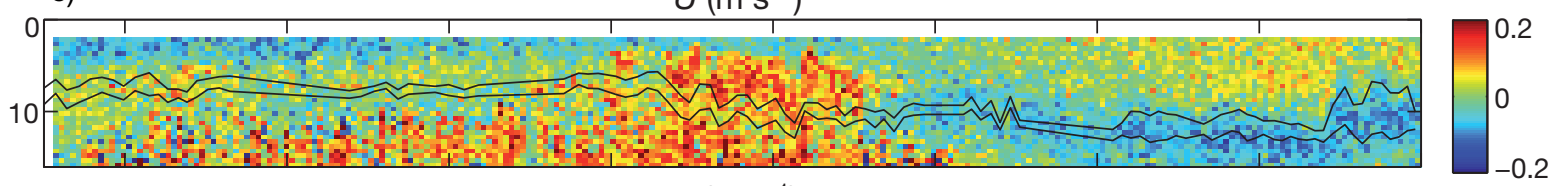

d) $\quad V\left(\mathrm{~m} \mathrm{~s}^{-1}\right)$

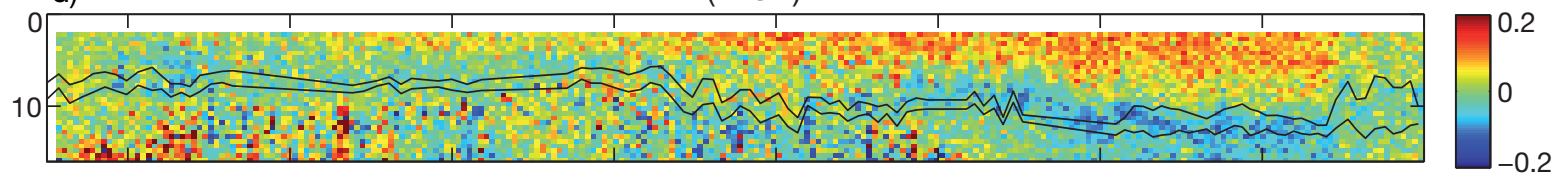

e) $\quad \mathrm{T}\left({ }^{\circ} \mathrm{C}\right)$
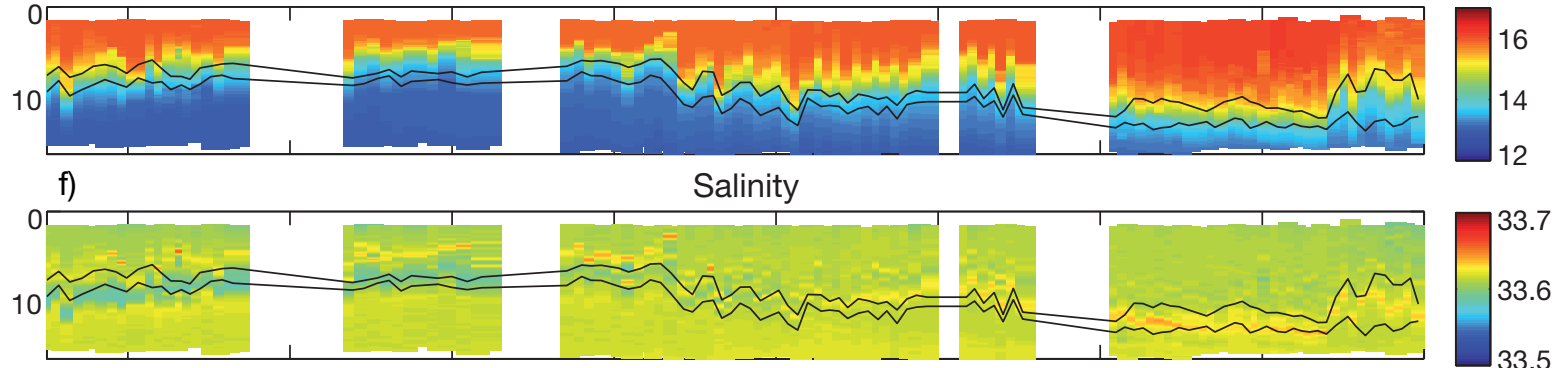

g)

$\sigma_{\mathrm{t}}\left(\mathrm{kg} \mathrm{m}^{-3}\right)$

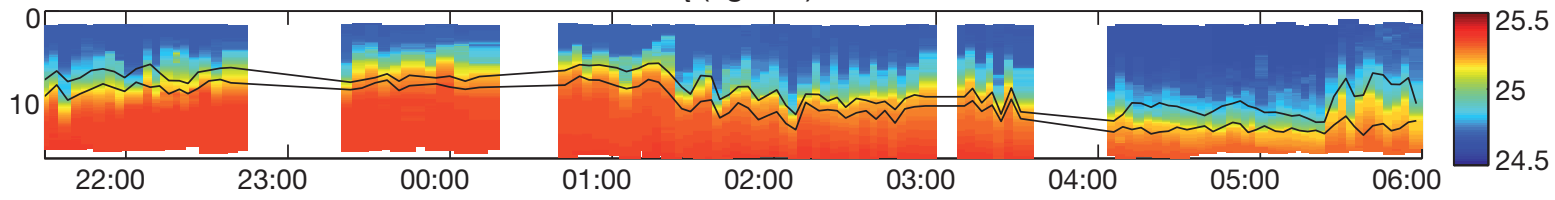

(h:min) Aug 26-27, 2005

Fig. 5. Time series of data from 21:30 h on Aug 26 to 06:00 h on Aug 27, 2005. (a) Water level (m) from the Stn W acoustic Doppler current profiler (ADCP), (b) $\mathrm{a}_{\mathrm{p}} 440\left(\mathrm{~m}^{-1}\right)$, (c) eastward $(U)$ and $(\mathrm{d})$ northward $(V)$ current velocity $\left(\mathrm{m} \mathrm{s}^{-1}\right)$ measured by the vesselmounted $\mathrm{ADCP}$, and profiler measurements of $(\mathrm{e})$ temperature $\left({ }^{\circ} \mathrm{C}\right)$, (f) salinity, and $(\mathrm{g}) \sigma_{t}\left(\mathrm{~kg} \mathrm{~m}^{-3}\right)$. Solid black lines indicate the upper and lower boundaries of the $\mathrm{a}_{\mathrm{p}} 440$ layer. For (b) to $(\mathrm{g}), y$-axis is depth (m)

internal wave packet from 04:00 to 05:00 h, the pycnocline gradually deepened from $\sim 5.6$ to $12.5 \mathrm{~m}$ and displayed no large vertical oscillations (Fig. $5 \mathrm{~g}$ ). Also during this period, the in-layer $\mathrm{a}_{\mathrm{p}} 440$ values decreased by $\sim 30 \%$ (Fig. 5b). The second internal wave packet was observed starting at $\sim 05: 25 \mathrm{~h}$ (Fig. 5). At the onset of this second internal wave packet, the upper boundary of the $\mathrm{a}_{\mathrm{p}} 440$ layer jumped $4.8 \mathrm{~m}$ (from $\sim 12.1$ to $7.3 \mathrm{~m}$ depth) and the pycnocline jumped $3.5 \mathrm{~m}$ (from $~ 12.5$ to $9.0 \mathrm{~m}$ depth; Figs. 5b,g \& $7 \mathrm{a}, \mathrm{b})$. This rapid shoaling occurred over a $7 \mathrm{~min}$ period ( 3 profiles).

\section{Conditions within the thin layer}

Throughout the survey, the mean in-layer shear and $N^{2}$ values remained fairly constant at $\sim 0.06 \mathrm{~s}^{-1}$ and $0.0005 \mathrm{~s}^{-2}$, respectively (Fig. 8a,b). With the exception of 2 profiles, mean in-layer $R i$ values were $>0.25$ for the entire survey (Fig. 8c). From 21:30 to 23:30 h, both layer thickness and the change in $\sigma_{\mathrm{t}}$ over the vertical extent of the layer $\left(\Delta \sigma_{t}\right)$ gradually decreased (Fig. 8d,e). The same parameters fluctuated over the period 01:00 to 03:30 h (Fig. 8e), with variance coefficients of $\sim 31$ and 


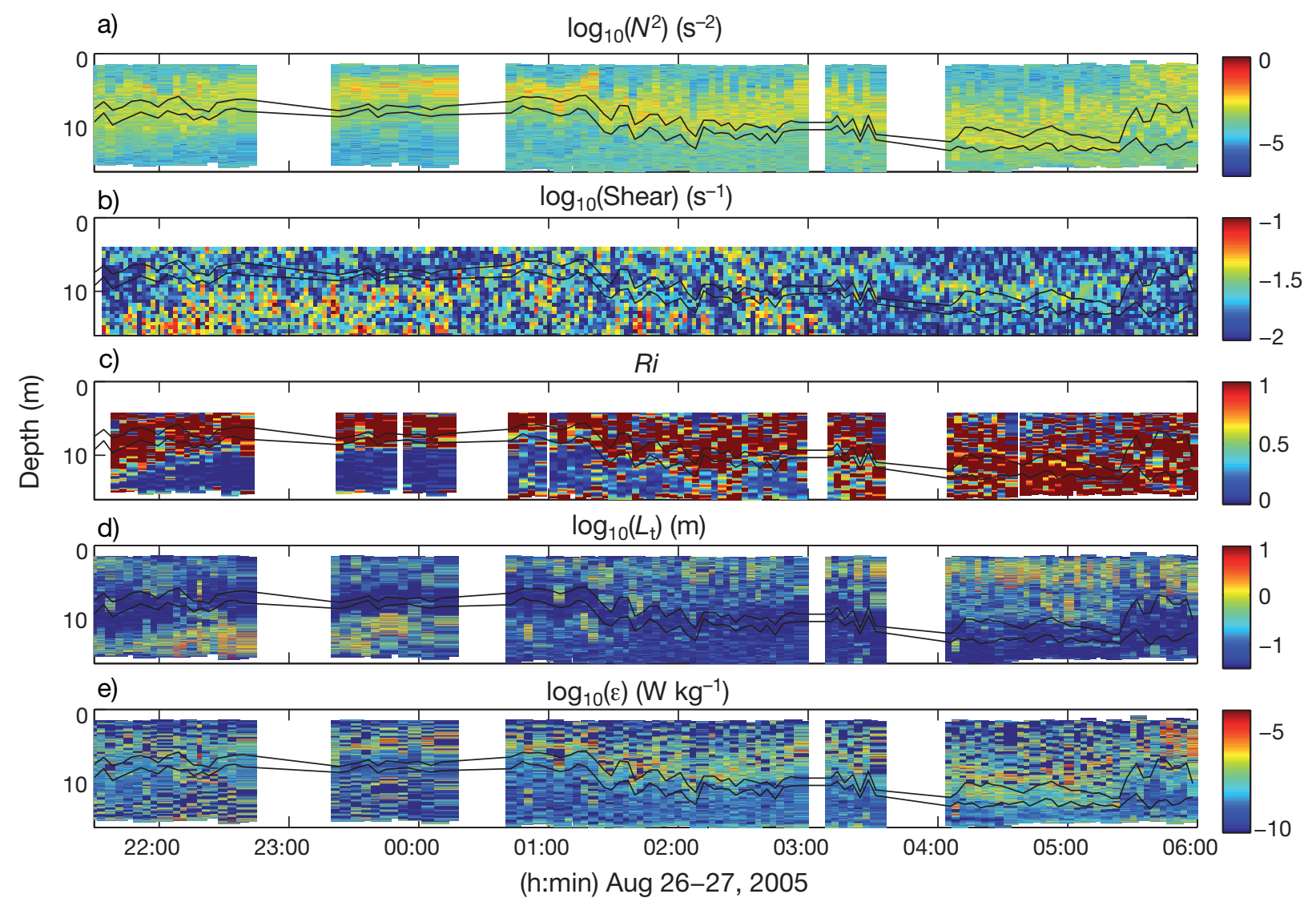

Fig. 6. Time series of data from 21:30 h on Aug 26 to 06:00 h on Aug 27, 2005. $\log _{10}$ of (a) squared Brunt-Väisälä frequency (s ${ }^{-2}$ ) and (b) shear $\left(\mathrm{s}^{-1}\right),(\mathrm{c})$ Richardson number, $\log _{10}$ of $(\mathrm{d})$ Thorpe scale $(\mathrm{m})$ and (e) turbulent dissipation rate (W kg $\left.{ }^{-1}\right)$. Solid black lines indicate the upper and lower boundaries of the $\mathrm{a}_{\mathrm{p}} 440$ layer
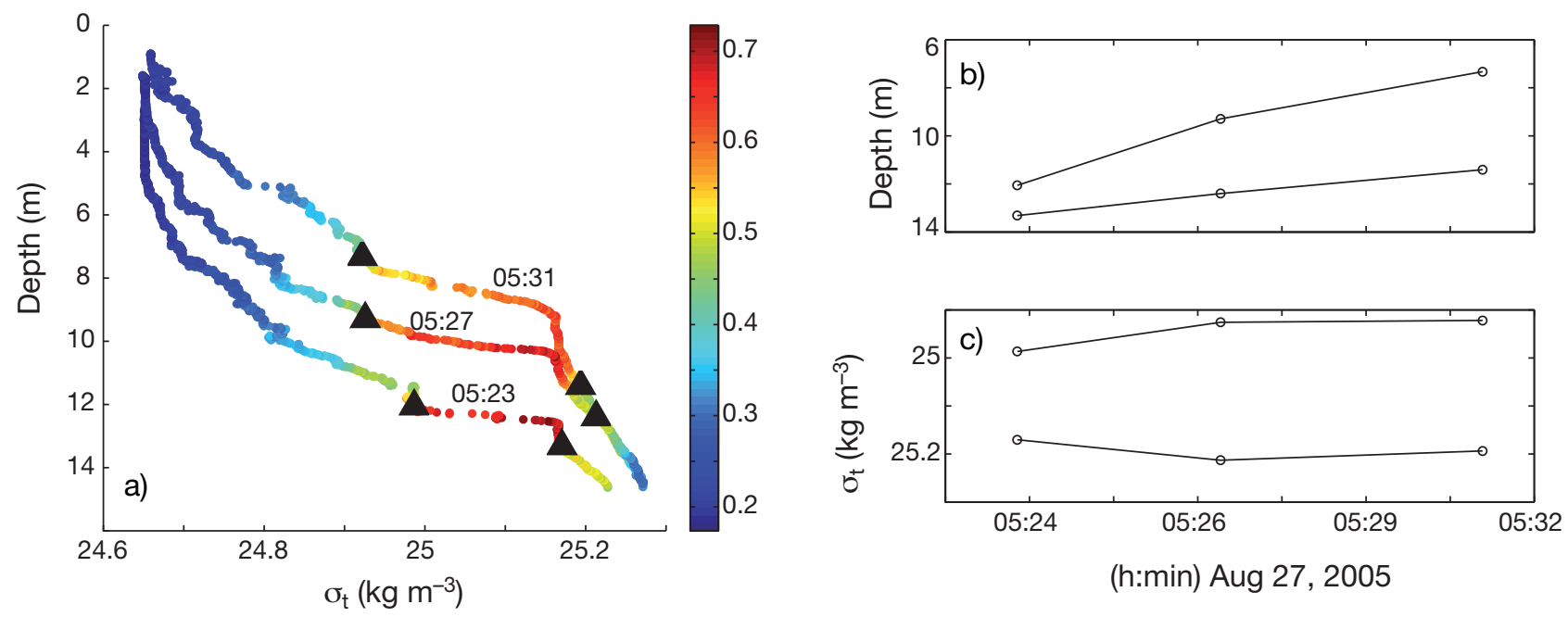

Fig. 7. Three $\sigma_{t}$ profiles collected from 05:23 to 05:31 h. (a) $\sigma_{t}$ profiles with overlaid upper and lower boundaries of thin layer $(\mathbf{\Delta})$; color scale is $\mathrm{a}_{\mathrm{p}} 440\left(\mathrm{~m}^{-1}\right)$. (b) Depth and (c) $\sigma_{\mathrm{t}}$ at the upper and lower boundaries over the time period of the 3 profiles

$41 \%$, respectively. Beginning at 04:00 h, $\Delta \sigma_{\mathrm{t}}$ increased by $\sim 85 \%$, while layer thickness increased by $62 \%$ over the course of 16 min (6 profiles) (Fig. 8d,e). Over this same time period, the bottom boundary of the thin layer only deepened by $\sim 0.02 \mathrm{~m}$, while the upper boundary shoaled by $\sim 1.96 \mathrm{~m}$. At the onset of the second internal 
a) $\log _{10} N^{2}\left(S^{-2}\right)$

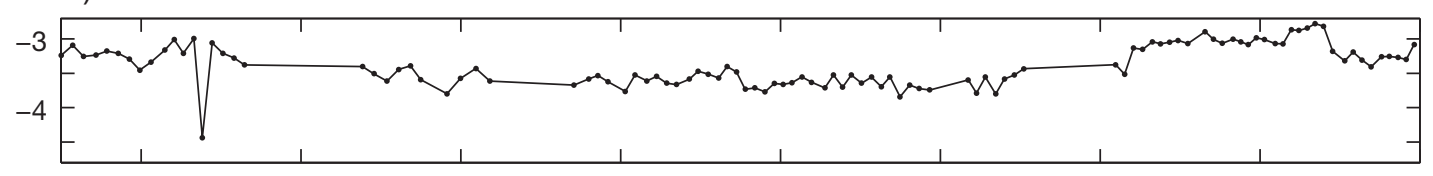

b)

Shear $\left(\mathrm{S}^{-1}\right)$

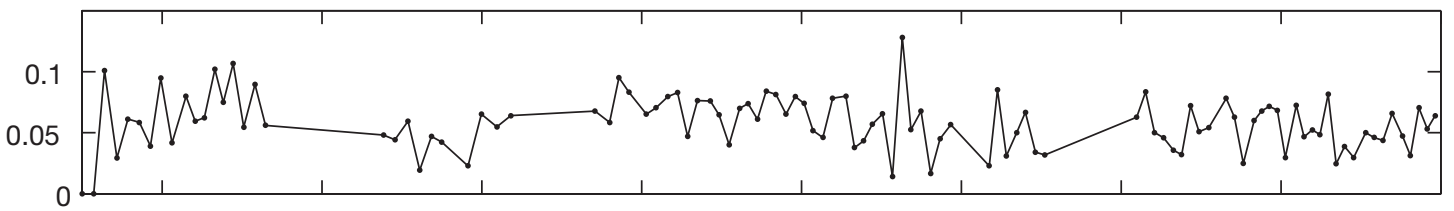

c)

Ri

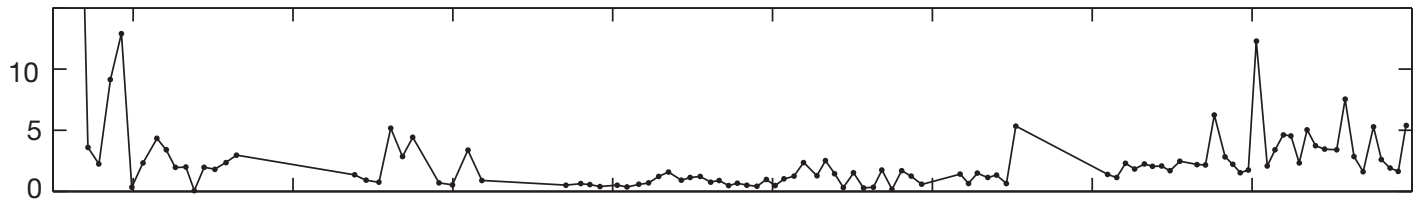

d) $\Delta z(m)$
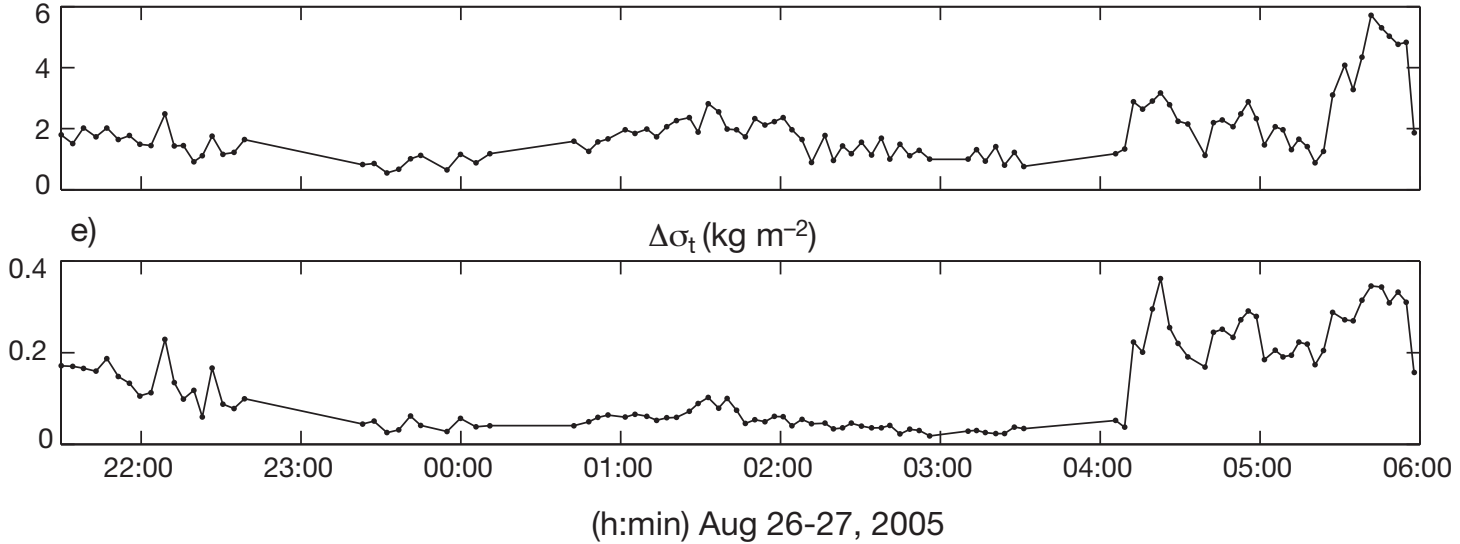

Fig. 8. Time series of data from 21:30 h on Aug 26 to 06:00 h on Aug 27, 2005. Mean in-layer values of (a) $\log _{10}$ squared BruntVäisälä frequency, (b) shear and (c) Richardson number; also plotted are the changes in (d) layer thickness $z$ and (e) $\sigma_{t}$ over the upper and lower boundaries of the thin layer

wave packet $(05: 25 \mathrm{~h})$, layer thickness increased by $>500 \%$ over the course of $21 \mathrm{~min}$ ( 7 profiles), while $\Delta \sigma_{\mathrm{t}}$ increased by only $100 \%$ over the same period (Figs. $7 \&$ $8 d, e)$. From $05: 41$ to $05: 48$ h ( 3 profiles), the phytoplankton layer thickness exceeded $5 \mathrm{~m}$ and no longer met our definition of a thin layer.

\section{Organisms within the layer}

Water samples taken during this experiment indicated that the predominant phytoplankton species comprising the thin layer was the dinoflagellate species Akashiwo sanguinea (J. Rines pers. comm.). These cells had a roughly ellipsoid shape, with length, width and height axes of 75, 50, and $\sim 12 \mu \mathrm{m}$ (J. Rines pers. comm.); we chose to use an average cell diameter of $65 \mu \mathrm{m}$ for Eq. (5). While these dinoflagellates are generally considered to be negatively buoyant, having a reported cell-specific density $\rho_{\mathrm{c}}$ of $1073 \pm 7 \mathrm{~kg} \mathrm{~m}^{-3}$ (Kamykowski et al. 1992), they are also capable vertical migrators (Park et al. 2002, Smayda 2002). We used the swimming velocity $W_{\mathrm{s}}=298 \mu \mathrm{m} \mathrm{s}^{-1}$, based on the in vitro observations made by Park et al. (2002). This value is in the upper range of swimming speeds recorded for this dinoflagellate (Smayda 2002), but is similar to the vertical migration speeds observed by other optical profilers deployed at this time in our study region (J. Sullivan pers. comm.). 


\section{Convergence mechanisms}

Hourly SeaHorse profiles from Stn W (Fig. 1) indicate the timing of layer formation. On 26 Aug, the fluorescence profile completed at 17:00 h showed a broad surface fluorescence patch, while the next profile, completed at 18:00 h, showed that this patch had migrated to deeper water. While the SeaHorse profiler was $2 \mathrm{~km}$ away from our sampling site, the observations by other researchers' optical profilers deployed in the region suggest that the chl a layer observed by the SeaHorse profiler was the same layer observed by the shipboard profiler, and that the diel migration pattern was coincident across the entire layer (J. Sullivan pers. comm.). Although these observations indicate a motilitydominated formation mechanism, we will assume a similar start time of $17: 30 \mathrm{~h}$ in analyzing the effects of straining.

The mean observed rate of change of layer thickness $(\partial l / \partial t)_{n e t}$ was on a scale of $\mathrm{mm} \mathrm{s}^{-1}$ (Table 1$)$. The mean rates of change of layer thickness attributed to straining by shear, settling and motility were found to be 1 to 4 orders of magnitude less than $(\partial l / \partial t)_{n e t}$ (Table 1$)$. Only in the 9 profiles collected during slack tide was the mean rate of change of layer thickness due to motility of the same order of magnitude as $(\partial l / \partial t)_{\text {net }}$ $\left(7.95 \times 10^{-4} \mathrm{~m} \mathrm{~s}^{-1}\right.$ and $5.96 \times 10^{-4} \mathrm{~m} \mathrm{~s}^{-1}$, respectively) . As indicated by the convergence rates in Table 1, the motility mechanism is an order of magnitude stronger than either straining or buoyancy, which is consistent with the assumption of a layer formed by diel migrations.

The greatest rates of change in layer thickness occurred during the 2 internal wave packets. However, because each vertical profile took $\sim 4$ min to complete and the thermistor data indicates that the period of these internal wave packets was 9 to $13 \mathrm{~min}$, it is likely that the rate of change in layer thickness during this period was under-sampled. To estimate the maximum $\partial 1 / \partial t$ due to internal waves, we can examine the rate of spreading and narrowing between the isotherms associated with the upper and lower boundaries of the

Table 1. Mean absolute value $( \pm \mathrm{SD})$ of the rate of change of layer thickness for the 3 convergence mechanisms and the net (i.e. measured) rate of change of layer thickness in both vertical space $\left(\mathrm{m} \mathrm{s}^{-1}\right)$ and $\sigma_{t}$ space $\left(\mathrm{kg} \mathrm{m}^{-3} \mathrm{~s}^{-1}\right)$

\begin{tabular}{|lcc|}
\hline \multicolumn{1}{c}{$\frac{\partial l}{\partial t}$} & $\frac{\partial\left(\Delta \sigma_{t}\right)}{\partial t}$ \\
\hline Nechanism & $2.10 \times 10^{-3} \pm 2.20 \times 10^{-3}$ & $1.18 \times 10^{-4} \pm 1.67 \times 10^{-4}$ \\
Motility & $5.96 \times 10^{-4} \pm 0.08 \times 10^{-4}$ & $6.06 \times 10^{-5} \pm 1.35 \times 10^{-4}$ \\
Straining & $5.82 \times 10^{-5} \pm 3.15 \times 10^{-5}$ & $6.83 \times 10^{-6} \pm 1.82 \times 10^{-5}$ \\
Settling & $2.60 \times 10^{-7} \pm 2.01 \times 10^{-7}$ & $3.03 \times 10^{-8} \pm 7.00 \times 10^{-8}$ \\
\hline
\end{tabular}

thin layer $\left(13.61 \pm 0.09\right.$ and $13.24 \pm 0.02^{\circ} \mathrm{C}$, respectively). The depth of these isotherms was determined by interpolating the thermistor chain temperature data. The greatest spreading between these isotherms occurred at the crests and troughs of the internal waves, with the distance between the isotherms ranging between $\sim 1.5$ and $3.5 \mathrm{~m}$ (Fig. 9). The rate of change of this distance ranged between 0 and $11 \mathrm{~cm} \mathrm{~s}^{-1}$ and had a mean value of $\sim 1 \mathrm{~cm} \mathrm{~s}^{-1}$, which is roughly equivalent to the maximum observed $\partial 1 / \partial t$ of the thin layer $\left(0.9 \mathrm{~cm} \mathrm{~s}^{-1}\right)$.

Assuming that the changes in layer thickness due to these internal wave fluctuations are somewhat constrained by isopycnals, we can remove most of the effects of the internal wave expansions and contractions by moving the Stacey et al. (2007) mathematical framework into $\sigma_{t}$ space. First, we consider

$$
\left(\frac{\partial\left(\Delta \sigma_{t}\right)}{\partial t}\right)_{n e t}=\left(\frac{\partial\left(\Delta \sigma_{t}\right)}{\partial t}\right)_{c o n v}+\left(\frac{\partial\left(\Delta \sigma_{t}\right)}{\partial t}\right)_{d i v}
$$

where $\Delta \sigma_{t}$ is the change in $\sigma_{t}$ over the boundaries of the layer. The first term in Eq. (12) was determined using the observed change in $\sigma_{\mathrm{t}}$ across the layer (Fig. 8e). The rates of change in layer thickness in $\sigma_{t}$ space due to the 3 convergent mechanisms, as determined using Eqs. (6), (9), (10) \& (11), can be converted into $\sigma_{t}$ coordinates using the chain rule:

$$
\left(\frac{\partial\left(\Delta \sigma_{t}\right)}{\partial t}\right)_{\text {conv }}=\left(\frac{\partial\left(\Delta \sigma_{t}\right)}{\partial l}\right)_{\text {conv }}\left(\frac{\partial l}{\partial t}\right)_{\text {conv }}
$$

where the second term is the local gradient of $\sigma_{t}$ across the layer. Similar to the analysis based on the 9 profiles collected during slack tide, the results of these calculations in $\sigma_{\mathrm{t}}$ space further support the supposition that this thin layer was formed and maintained by the swimming behavior of phytoplankton. Looking at the entire survey period in $\sigma_{t}$ space, the mean rate of change due to motility over the entire survey is still an order of magnitude less than that of the net (observed) $\partial\left(\Delta \sigma_{t}\right) / \partial t$ (Table 1). We can parse this analysis into 4 time periods of continuous sampling: (1) end of ebb tide (21:30 to 22:40 h, 15 profiles); (2) slack tide (23:20 to 00:10 h, 9 profiles); (3) start of flood tide (00:40 to $03: 30$ h, 42 profiles); and (4) end of flood tide (04:00 to 06:00 h, 33 profiles). Closer examination of the mean $\partial\left(\Delta \sigma_{t}\right) / \partial t$ over these 4 separate periods reveals that, for periods 1 to 3 , $\left(\partial\left(\Delta \sigma_{t}\right) / \partial t\right)_{\text {motil }}$ was of the same order of magnitude as $\left(\partial\left(\Delta \sigma_{t}\right) / \partial t\right)_{n e t}$, and declined only to $30 \%$ of the latter (Fig. 10). However, during period 4 , the mean 


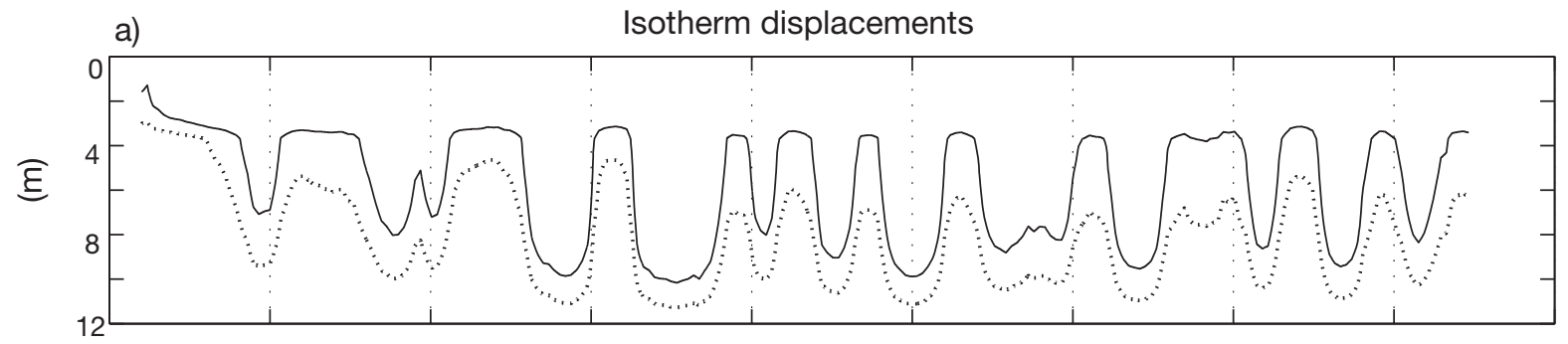

b)

Vertical distance between isotherms

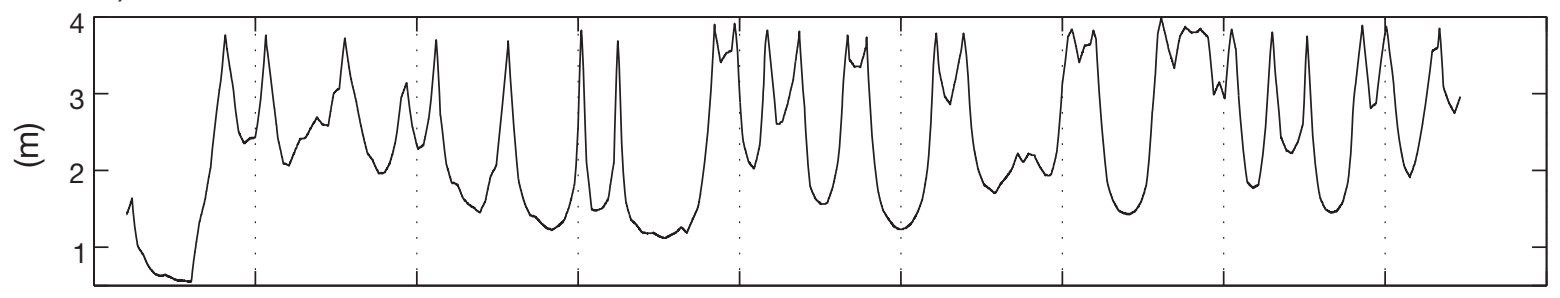

c) Rate of isotherm spreading

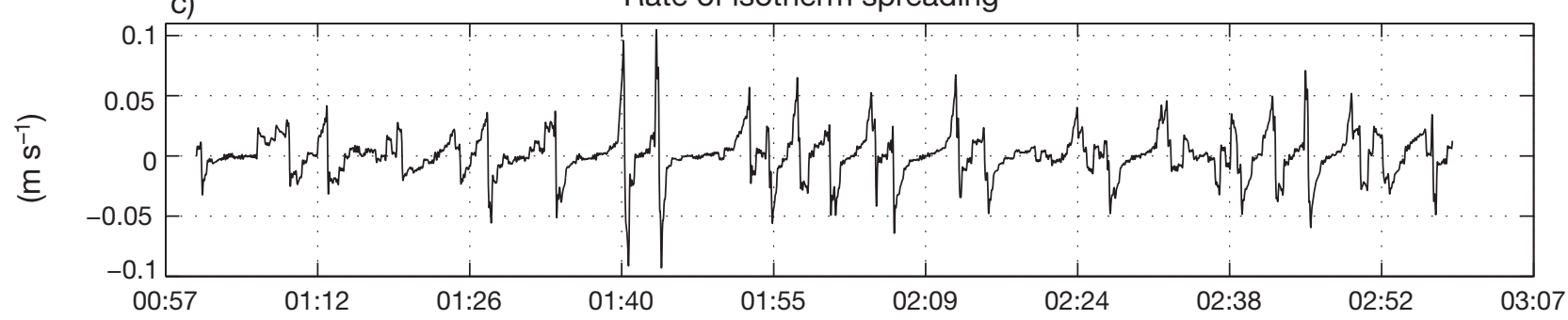

(h:min) Aug 27, 2005

Fig. 9. Data from the Stn E thermistor chain during the passage of the first internal wave packet. (a) Displacement of $13.24^{\circ} \mathrm{C}$ (solid) and $13.62^{\circ} \mathrm{C}$ (dotted) isotherms, (b) vertical distance between the isotherms, and (c) rate of isotherm spreading

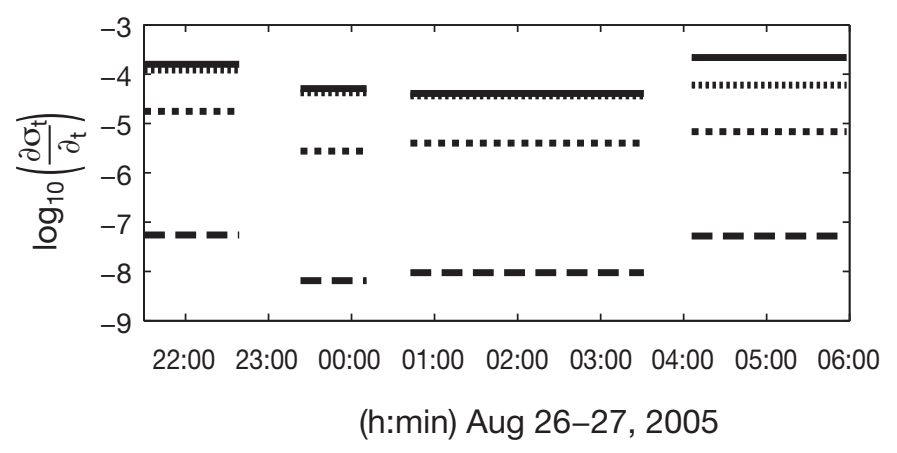

Fig. 10. $\log _{10}$-scale of mean rates of change in layer thickness in $\sigma_{\mathrm{t}}$ space $\left(\mathrm{kg} \mathrm{m}^{-3} \mathrm{~s}^{-1}\right)$ for the net (i.e. measured) rate of change of layer thickness (solid) and the rates calculated (using the Stacey et al. 2007 model) for phytoplankton motility (dotted), shear (medium dash), and settling (large dash) for 4 periods of continuous sampling

observed $\partial\left(\Delta \sigma_{t}\right) / \partial t$ was $>200 \%$ that of motility (Fig. 10), suggesting that the swimming ability of the cells alone could not account for the observed expansion of the layer during this period.

\section{DISCUSSION}

During the summer of 2005, the phytoplankton community in Monterey Bay was dominated by the strongswimming dinoflagellate Akashiwo sanguinea (Rines et al. 2006). At night, surface patches of $A$. sanguinea migrated out of the nutrient-depleted surface waters to form thin layers in the more nutrient-replete waters at depth (Donaghay et al. 2006). Although the swimming behavior of these dinoflagellates most likely caused the formation of the thin layer we observed, the mechanism that had the greatest effect on changes in layer thickness throughout its duration, once it was established at depth, was the passage of internal wave packets.

\section{Anomalous physical and biological conditions}

When assessing the likelihood of thin layer formation in a given environment, it is important to consider not 
only the present seed population, but also the largescale processes that govern these biological populations. In the summer of 2005, anomalous physical and biological conditions within the California Current System (CCS) likely resulted in the dinoflagellatedominated phytoplankton assemblage observed in Monterey Bay during our study period.

From March to October, the subtropical high-pressure cell over the Pacific typically produces winds from the northwest along the California coast. These winds drive the upwelling of cold, high-nutrient water at coastal points and headlands (Breaker \& Broenkow 1994). At Pt. Año Nuevo, an upwelling center 20 miles north of Monterey Bay, the upwelled water bifurcates, with one tongue flowing equator-ward and offshore and the other extending across the mouth of Monterey Bay (Rosenfeld et al. 1994). The temperature and nutrient characteristics of this upwelled water are generally thought to be conducive to highly productive, diatom-dominated phytoplankton blooms (Hood et al. 1990, Pennington \& Chavez 2000, Wilkerson et al. 2000). However, a very different phytoplankton community was observed in Monterey Bay during the summer of 2005 (Rines et al. 2006, R. Jester pers. comm.). This atypical phytoplankton assemblage was most likely caused by changes in the predominant physical regime along the west coast of the US during this period (Barth et al. 2007).

In the spring of 2005, a nearly 2 mo delay in the onset of upwelling-favorable winds resulted in anomalous physical, chemical and biological conditions throughout the CCS, affecting regions from Vancouver Island to Baja California (Hickey et al. 2006, Kudela et al. 2006, Barth et al. 2007). The effects of the delayed onset of upwelling-favorable winds (higher nearshore surface temperatures, lower nutrient concentrations, and below-average primary production) were most pronounced in shelf waters along the Oregon and Washington coast (Hickey et al. 2006, Barth et al. 2007). However, although the central California coast experienced relatively normal (i.e. upwellingfavorable) wind forcing throughout the summer of 2005, Schwing et al. (2006) emphasizes that the anomalous conditions observed in the CCS were more strongly impacted by the delayed onset of these winds than the cumulative amount of upwelling that followed. Also, Hickey et al. (2006) notes that the local oceanographic conditions in different regions of the CCS are not only strongly affected by local winds, but also by remote forcing. As a result, the delayed onset of upwelling coupled with the anomalous conditions off the Oregon and Washington coasts may have significantly affected and altered the Central California marine ecosystem. While the consequences of the delayed onset of upwelling were most strongly expressed in the biological communities in upper trophic levels (Sydeman et al. 2006, Weise et al. 2006), we hypothesize that these conditions also resulted in the observed dinoflagellate-dominated phytoplankton assemblage observed in Monterey Bay during our study period.

\section{Thin layer formation}

At the time of our study in Monterey Bay, the observed phytoplankton community was extremely diverse, but the upper water column was dominated by the dinoflagellate Akashiwo sanguinea (Rines et al. 2006). Water samples indicate that $A$. sanguinea was the primary phytoplankton species comprising the thin layer we observed (J. Rines pers. comm.). A myriad of diatom species was also found in near-bottom waters, but the majority were observed to be in poor structural condition. While dinoflagellates are not typically effective competitors against diatoms in moderately energetic, high-nutrient upwelling regions (Walsh et al. 1974, Smayda 1997), the anomalous conditions along the west coast of the USA in the spring and summer of 2005, and the distribution of available nutrients, may have been particularly suited to dinoflagellate blooms. Off the coast of Oregon, mean nutrient concentrations in 2005 were $30 \%$ below average levels (Barth et al. 2007). Exceptionally low nutrient concentrations were observed in the nearshore surface waters of Monterey Bay, with a steep nutricline present at depth (Hanson et al. 2006).

Because Akashiwo sanguinea are highly motile, with reported in vitro swimming speeds of 32 to $410 \mu \mathrm{m} \mathrm{s}^{-1}$ (Park et al. 2002, Smayda 2002), it is likely that these phytoplankton were able to reach the nutrients at depth via diel migration. In August of 2005, Donaghay et al. (2006) observed populations of $A$. sanguinea migrating out of the nutrient-depleted surface water at night to more nutrient-rich waters at depth where they formed thin layers at the depth of the nutricline. Our estimated rates of layer convergence in $\sigma_{t}$ space support the hypothesis that these layers were formed by diel migration patterns. How dinoflagellates exploit their motility to take advantage of nutrient gradients through vertical migrations, depth-keeping and subsurface layers is well documented by both laboratory and in situ studies (Eppley \& Harrison 1975, Holligan 1979, 1987, Smayda 1997). In addition, thin $(<5 \mathrm{~m}$ thick), subsurface layers of dense dinoflagellate blooms have been observed in a variety of habitats (Kiefer \& Lasker 1975, Lasker \& Zeifel 1978, Bjørnsen \& Nielsen 1991). Throughout our survey, the thin layer was consistently co-located with the narrow region of near-zero overturning $\left(L_{\mathrm{t}}\right)$ scales (Fig. 6d). During ebb tide, the elevated $L_{\mathrm{t}}$ scales below the layer may have 
been effective at transporting nutrients across the nutricline and towards the layer (Fig. 6d). As the tide began to flood, overturning scales below the layer decreased and the thin layer deepened and lessened in intensity. Also during flood tide, the upper boundary of the layer was characterized by elevated turbulent dissipation $(\varepsilon)$ rates (Fig. 6e). The higher $\varepsilon$ values, combined with the narrow region of elevated shear located just above the thin layer, may have contributed to the thinning of the patch by eroding the top part of the layer (Fig. 6b,d). Grazing by zooplankton on the edges of this layer may have also contributed to the thinning of the patch (V. Holliday pers. comm.).

\section{Controls on layer thickness}

With the data from this study, we had a unique opportunity to apply the mathematical model put forth by Stacey et al. (2007) in order to test the effectiveness of different convergence mechanisms in thinning and maintenance of a thin layer of phytoplankton. While the average net rate of change in layer thickness was small $\left(\sim 2 \mathrm{~mm} \mathrm{~s}^{-1}\right)$, all of the considered convergence mechanisms - straining by shear, settling, and cell motility-had associated thinning rates that were orders of magnitude less than this observed rate (Table 1). Except during one $20 \mathrm{~min}$ period during slack tide, these 3 mechanisms, even taken together, could not account for the observed rates of change in layer thickness. We hypothesize that this was due to internal waves expanding and contracting the layer on relatively short time scales. Internal waves are regular features over the Monterey Bay shelf and occur most frequently during the transition from spring to neap tide and when the tidal range is between 1.5 and $1.7 \mathrm{~m}$ (Storlazzi et al. 2003). While our overnight study took place between neap and spring tide, the maximum tidal range was just over $1.5 \mathrm{~m}$ (Figs. 4b \& 5a). Storlazzi et al. (2003) observed that during the transition from ebb to flood tide, warm bore-like internal tide features move onto the shelf, causing a sudden warming and reversal of depth-averaged currents. In spring and summer months, packets of 8 to 10 internal waves follow the heads of these bore-like features (Storlazzi et al. 2003). Because these internal waves are associated with internal tides and bore-like features generated at the shelf-break, they can be extremely energetic (Ostrovsky \& Stepanyants 1989). McManus et al. (2005) observed a close relationship between internal wave heights and the average vertical thickness of zooplankton layers; an increase in internal wave height often corresponded to an increase in the thickness of the layer, and $\sim 40 \%$ of the variability in mean layer thickness could be attributed to internal wave height.
Similarly, the largest changes in layer thickness we observed in the present study occurred during the passage of internal waves. During the surface flood tide period of our study, we observed 2 internal wave packets that were $2 \mathrm{~h}$ apart (Fig. 5). The vertical fluctuations due to these 2 internal wave packets, especially the second one, strongly affected the vertical thickness of the layer (Fig. 7d). During the first internal wave packet ( 01:00 to 03:30 h), the changes in layer thickness in both physical and $\sigma_{\mathrm{t}}$ space exhibited moderate vertical fluctuations and rapid changes in thickness (Fig. 8d). Although the frequency of the vertical profiles under-sampled this internal wave signal and subsequently underestimated the rate of change in layer thickness during this period, the mean rate of spreading and divergence of thermistor-chain isotherms is of the same order of magnitude as the maximum observed rate of change in layer thickness $\left(\sim 10^{-2} \mathrm{~m} \mathrm{~s}^{-1}\right.$; Fig. 9). After these vertical fluctuations ended, however, both the thickness and the intensity of the layer remained relatively unchanged compared to the initial (01:00 h) values.

In contrast, the second set of internal waves corresponded to large changes in both $\Delta z$ and $\Delta \sigma_{t}$, and we hypothesize that this caused the rapid broadening of the layer. At the onset of the second internal wave packet at 05:25 h, the upper boundary of the thin layer shoaled rapidly $\left(\sim 8 \mathrm{~mm} \mathrm{~s}^{-1}\right.$; Fig. 7$)$. This rate of shoaling far exceeds the fastest observed swimming speeds of Akashiwo sanguinea (Smayda 2002). While the physical space between the upper and lower boundaries of the thin layer increased by $>220 \%$, the $\Delta \sigma_{t}$ between these boundaries only changed by $50 \%$ (Fig. 7), suggesting that the observed change in layer thickness was caused by isopycnals spreading with the onset of this internal wave packet. Previous observations of thin zooplankton layers in Monterey Bay have noted that, while they were frequently modulated by internal waves, the fluctuations did not cause the layers to dissipate (McManus et al. 2005, Cheriton et al. 2007). However, Sevadjian (2008) reported the temporary dispersion of a thin zooplankton layer in Mamala Bay, Hawaii, during the passage of internal waves.

The rapid shoaling at 05:25 $\mathrm{h}$ is also evident in the physical data (Figs. $5 \& 6$ ). The high-salinity layer, the pycnocline, and the region of low $L_{\mathrm{t}}$ associated with the layer all exhibited similar shoaling. Current velocity also changed in vertical structure. The southwesterly (offshore) flow associated with the layer also shoaled and expanded (Fig. 5d), while the 2-layer flow structure lessened in strength (Fig. 5c). The abrupt changes in both biological and physical metrics might suggest the advection of a frontal feature across our profiling site. Indeed, J. Ryan et al. (unpubl. data) report locally enhanced fluorescence light height lev- 
els at a frontal boundary associated with intrusions of low-salinity offshore waters into the shelf waters of Monterey Bay. However, while the advection of a frontal feature across our profiling site could cause the observed increase in layer thickness and decrease in layer intensity, the temperature and salinity data do not show evidence for such a feature.

It is also unlikely that phytoplankton motility led to the observed layer broadening. The rate of layer broadening from 05:25 to 05:31 h exceeded the swimming speeds of Akashiwo sanguinea by several orders of magnitude. In addition, after temporarily broadening to $>5 \mathrm{~m}$ (05:41 to 05:48 h), the layer thickness decreased back to $\sim 2 \mathrm{~m}$ (Fig. 8d). Furthermore, the observed broadening of the thin layer occurred $30 \mathrm{~min}$ prior to the beginning of civil twilight (06:08 $h_{\text {; }}$ (http:// aa.usno.navy.mil) and $1 \mathrm{~h}$ before sunrise (06:35 h).

\section{CONCLUSIONS}

In August 2005, we conducted an overnight survey of thin layers in Monterey Bay using a high-resolution profiler. Over an $8.5 \mathrm{~h}$ period, we collected 99 vertical profiles and observed a dense thin layer of Akashiwo sanguinea at the base of the pycnocline, co-located with a thin region of salinity anomalies. The vertical structure of the layer and the water column indicates that motility was more effective than either straining or buoyancy in forming and maintaining the observed layer. However, the calculated rates of change in layer thickness due to these 3 mechanisms alone could not account for the observed changes in layer thickness. This discrepancy is due to the displacement of the layer by internal waves. The isotherms that bounded the layer were found to be spreading and diverging at a mean rate roughly equivalent to the maximum observed rate of change in layer thickness $\left(10^{-2} \mathrm{~m} \mathrm{~s}^{-1}\right)$. We conclude that greater rates of change in layer thickness occurred with the passage of these internal waves, but the slow frequency of the vertical profiles smeared this signal. When accounting for the effects of isopycnal expansion and contraction in the mathematical framework, phytoplankton motility emerges as a plausible mechanism for layer convergence. In density coordinates, the mean rate of convergence due to motility is of the same order of magnitude as the observed rates of change, except during the passage of the second internal wave, during which the layer broadened rapidly.

We hypothesize that the isopycnal spreading associated with the onset of an internal wave packet directly caused the broadening of the observed thin phytoplankton layer. Consequently, although the formation and maintenance of this thin layer may have been dri- ven by the vertical migration and depth-keeping of the strong-swimming A. sanguinea, the physical forcing by internal waves had the potential to exert greater influence on the thickness of the layer and override the depth-keeping ability of the phytoplankton. Thus, for a model to accurately describe the convergence and divergence processes governing the boundaries of a thin layer in a region subject to internal waves, it must take into account the effects of internal wave motion.

Acknowledgements. We thank the Captain of RV 'Shana Rae', J. Christmann, for assistance with mooring deployments and the overnight survey. We are grateful to J. Ryan for providing an initial review of the manuscript as well as information about the results of nearby AUV transects. We thank the PIs and technicians of the Partnership for Interdisciplinary Studies of Coastal Oceans (PISCO, a long-term ecological consortium funded by the David and Lucile Packard Foundation and the Gordon and Betty Moore Foundation program) for providing time series of temperature data. We thank J. Fram, L. Goodman, A. Hanson, J. Lane, B. McLaughlin, S. Palacios, M. Reidenbach, J. Rines, G. Steward, J. Sullivan, Z. Wang, and C. Woodson for assistance in the field and/or helpful discussions about the data. We are grateful to C. Edwards, V. Holliday, R. Kudela, and M. Silver for providing invaluable comments on early drafts of the manuscript. We also thank 2 anonymous reviewers for their helpful and constructive comments. This research was supported by the Office of Naval Research, grant no. N00014-04-1-0311 to M.A.M., M.T.S., and J. P. Ryan).

\section{LITERATURE CITED}

Alldredge AL, Cowles TJ, MacIntyre S, Rines JEB and others (2002) Occurrence and mechanisms of formation of a dramatic thin layer of marine snow in a shallow Pacific fjord. Mar Ecol Prog Ser 233:1-12

Barth JA, Menge BA, Lubchenco J, Chan F and others (2007) Delayed upwelling alters nearshore coastal ocean ecosystems in the northern California current. Proc Natl Acad Sci USA 104:3719-3724

Bjørnsen PK, Nielsen TG (1991) Decimeter scale heterogeneity in the plankton during a pycnocline bloom of Gyrodinium aureolum. Mar Ecol Prog Ser 73:263-267

Breaker LC, Broenkow WW (1994) The circulation of Monterey Bay and related processes. Oceanogr Mar Biol Annu Rev 32:1-64

Cheriton OM, McManus MA, Holliday DV, Greenlaw CF, Donaghay PL, Cowles TJ (2007) Effects of mesoscale physical processes on thin zooplankton layers at four sites along the west coast of the U.S. Estuar Coast 30:575-590

Cowles T, Desiderio RA, Carr ME (1998) Small-scale planktonic structure: persistence and trophic consequences. Oceanography 11:4-9

Cowles TJ, Desiderio RA, Moum JN, Myrick ML, Garvis D, Angel SM (1990) Fluorescence microstructure using a laser/fiber optic profiler. Proc SPIE, Ocean Optics X 1302: 336-345

> Dekshenieks MM, Donaghay PL, Sullivan JM, Rines JEB, Osborn TM, Twardowski MS (2001) Temporal and spatial occurrence of thin phytoplankton layers in relation to physical processes. Mar Ecol Prog Ser 223:61-71

> Derenbach JB, Astheimer H, Hansen HP, Leach H (1979) Vertical microscale distribution of phytoplankton in relation to the thermocline. Mar Ecol Prog Ser 1:187-193 
Dillon TM (1982) Vertical overturns: a comparison of Thorpe and Ozmidov Length Scales. J Geophys Res 87:9601-9613

Donaghay PL, Osborn TR (1997) Toward a theory of biological-physical control of harmful algal bloom dynamics and impacts. Limnol Oceanogr 42:1283-1296

Donaghay PL, Rines HM, Sieburth JM (1992) Simultaneous sampling of fine-scale biological, chemical and physical structure in stratified waters. Ergeb Limnol 36:97-108

Donaghay PL, Sullivan JM, Rines JE, Graff J, Hanson AK, Holliday DV (2006) The importance of swimming behavior in controlling the formation, maintenance and dissipation of thin optical layers. Ocean Sci Meet Suppl, Abstract OS33M03. EOS Trans Am Geophys Union 87:36 (Abstract)

Eppley RW, Harrison WG (1975) Physiological ecology of Gonyaulax polyedra, a red water dinoflagellate of southern California. In: LoCicero VR (ed) Proc 1st Int Conf Toxic Dinoflagellate Blooms. Massachusetts Science and Technology Foundation, Wakefield, MA, p 11-22

Franks PJS (1992) Sink or swim: accumulation of biomass at fronts. Mar Ecol Prog Ser 82:1-12

Franks PJS (1995) Thin layers of phytoplankton: a model of formation by near-inertial wave shear. Deep Sea Res I 42: $75-91$

Gibson CH (1980) Fossil temperature, salinity, and vorticity turbulence in the ocean. In: Nihoul JCJ (ed) Marine turbulence. Elsevier, Amsterdam, p 221-257

Hanson A, Egli P, Sweetman R, Katz D, Donaghay P (2006) The role of nutrient gradients in the episodic formation of thin plankton layers in Monterey Bay, CA. Ocean Sci Meet Suppl, Abstract OS34M-01. EOS Trans Am Geophys Union 87:36 (Abstract)

- Hickey BM, MacFadyen A, Cochlan WP, Kudela R, Bruland KW, Trick CR (2006) Evolution of chemical, biological and physical water properties in the northern California Current in 2005: remote or local wind forcing? Geophys Res Lett 33:L22S02

Holliday DV, Pieper RE, Greenlaw CF, Dawson JK (1998) Acoustic sensing of small-scale vertical structures. Oceanography 11:18-23

Holliday DV, Donaghay PL, Greenlaw CF, McGehee DE, McManus MA, Sullivan JM, Miksis JL (2003) Advances in defining fine- and micro-scale patterns in plankton. Aquat Living Resour 16:131-136

Holligan PM (1979) Dinoflagellate blooms associated with tidal fronts around the British Isles. In: Taylor DL, Seliger $\mathrm{HH}$ (eds) Toxic dinoflagellate blooms. Elsevier/North Holland, New York, p 249-256

Holligan PM (1987) Marine dinoflagellate blooms: growth strategies and environmental exploitation. In: Anderson DM, White AW, Baden DG (eds) Toxic dinoflagellates. Elsevier, Amsterdam, p 133-139

Hood RR, Abbott MR, Huyer A, Kosro PM (1990) Surface patterns in temperature, flow, phytoplankton biomass, and species composition in the coastal transition zone off northern California. J Geophys Res 95:18081-18094

Itsweire EC, Osborn TR, Stanton TP (1989) Horizontal distribution and characteristics of shear layers in the seasonal thermocline. J Phys Oceanogr 19:301-320

Itsweire EC, Koseff JR, Briggs DA, Ferziger JH (1993) Turbulence in stratified shear flows: implications for interpreting shear-induced mixing in the ocean. J Phys Oceanogr 23: $1508-1522$

Kamykowski D, Reed RD, Kirkpatrick GJ (1992) Comparison of sinking velocity, swimming velocity, rotation and path characteristics among six marine dinoflagellate species. Mar Biol 113:319-328

Kiefer DA, Lasker R (1975) Two blooms of Gymnodinium splendens (Lebour), a large naked dinoflagellate. Fish Bull 73:675-678

Kudela RM, Cochlan WP, Peterson TD, Trick CG (2006) Impacts on phytoplankton biomass and productivity in the Pacific Northwest during the warm ocean conditions of 2005. Geophys Res Lett 33:L22S06

Kullenberg G (1975) Investigation of small-scale vertical mixing in relation to the temperature structure in stably stratified waters. Adv Geophys 18:339-351

Lasker R, Zeifel JR (1978) Growth and survival of first-feeding northern anchovy larvae (Engraulis mordax) in patches containing different proportions of large and small prey. In: Steele JH (ed) Spatial pattern in plankton communities. Plenum Press, New York, p 329-354

McManus MA, Alldredge AL, Barnard AH, Boss E and others (2003) Characteristics, distribution and persistence of thin layers over a 48-hour period. Mar Ecol Prog Ser 261:1-19

> McManus MA, Cheriton OM, Holliday DV, Greenlaw CF, Drake P (2005) Effects of physical processes on structure and transport of thin zooplankton layers in the coastal ocean. Mar Ecol Prog Ser 301:199-215

McManus MA, Kudela RM, Silver MV, Steward GF, Sullivan JM, Donaghay PL (2008) Cryptic blooms: Are thin layers the missing connection? Estuar Coast 31:396-401

McNown JS, Malaika J (1950) Effects of particle shape on settling velocity at low Reynolds numbers. Trans Am Geophys Union 31:74-82

Osborn TR (1998) Finestructure, microstructure, and thin layers. Oceanography 11:36-43

- Ostrovsky LA, Stepanyants YA (1989) Do internal solitons exist in the ocean? Rev Geophys 27:293-310

Park MG, Cooney SK, Kim JS, Coats WD (2002) Effects of parasitism on diel vertical migration, phototaxis/geotaxis, and swimming speed of the bloom-forming dinoflagellate Akashiwo sanguinea. Aquat Microb Ecol 29:11-18

> Pennington JT, Chavez FP (2000) Seasonal fluctuations of temperature, salinity, nitrate, chlorophyll and primary production at station H3/M1 over 1989-1996 in Monterey Bay, California. Deep Sea Res II 47:947-973

Pickard GL, Emery WJ (1990) Descriptive oceanography, 5th edn. Butterworth-Heinemann, Oxford

Pinkel R, Anderson S (1997a) Shear, strain and Richardson number variations in the thermocline. Part 1. Statistical description. J Phys Oceanogr 27:264-281

> Pinkel R, Anderson S (1997b) Shear, strain and Richardson number variations in the thermocline. Part 2. Modeling mixing. J Phys Oceanogr 27:282-290

Pond S, Pickard GL (1983) Introductory dynamical oceanography, 2nd edn. Butterworth-Heinemann, Oxford

Rines JEB, Donaghay PL, Dekshenieks MM, Sullivan JM, Twardowski MS (2002) Thin layers and camouflage: hidden Pseudo-nitzschia spp. (Bacillariophyceae) populations in a fjord in the San Juan Islands, Washington, USA. Mar Ecol Prog Ser 225:123-137

Rines J, McFarland M, Donaghay P, Sullivan J, Graff J (2006) Characterization of the Monterey Bay phytoplankton community during the 2005 LOCO (Layered Organization in the Coastal Ocean) experiment, and the importance of species-specific characteristics of the flora to the dynamics and properties of thin layers. Ocean Sci Meet Suppl, Abstract OS33M-05. EOS Trans Am Geophys Union 87:36 (Abstract)

> Rosenfeld LK, Schwing FB, Garfield N, Tracy DE (1994) Bifurcated flow from an upwelling center: a cold water source for Monterey Bay. Cont Shelf Res 14:931-939

Ryan JP, McManus MA, Paduan JD, Chavez FP (2008) Phytoplankton thin layers caused by shear in frontal zones of a coastal upwelling system. Mar Ecol Prog Ser 354:21-34 
Schwing FB, Bond JA, Bograd SJ, Mitchell T, Alexander MA, Mantua N (2006) Delayed coastal upwelling along the U.S. West Coast in 2005: a historical perspective. Geophys Res Lett 33:L22S01

Sevadjian JC (2008) The effect of physical structure and processes on thin zooplankton layers in Mamala Bay, Hawaii. MSc thesis, University of Hawaii at Manoa, Honolulu

Smayda TJ (1997) Harmful algal blooms: their ecophysiology and general relevance to phytoplankton blooms in the sea. Limnol Oceanogr 42:1137-1153

Smayda TJ (2002) Turbulence, watermass stratification and harmful algal blooms: an alternative view and frontal zones as 'pelagic seed banks'. Harmful Algae 1:95-112

Stacey MT, McManus MA, Steinbuck JV (2007) Convergences and divergences and thin layer formation and maintenance. Limnol Oceanogr 52:1523-1532

Storlazzi CD, McManus MA, Figurski JD (2003) Long-term, high-frequency current and temperature measurements along central California: insights into upwelling/relaxation and internal waves on the inner shelf. Cont Shelf Res 23:901-918

Editorial responsibility: Steven Morgan,

Bodega Bay, California, USA
Sydeman WJ, Bradley RW, Warzybok P, Abraham CL and others (2006) Planktivorous auklet Ptychoramphus aleuticus responses to ocean climate, 2005: unusual atmospheric blocking? Geophys Res Lett 33:L22S09

Thorpe SA (1977) Turbulence and mixing in a Scottish loch. Philos Trans R Soc Lond A 286:125-181

Twardowski MS, Sullivan JM, Donaghay PL, Zaneveld JRV (1999) Microscale quantification of the absorption by dissolved and particulate material in coastal waters with an ac-9. J Atmos Oceanic Technol 16:691-707

Walsh JJ, Kelley JC, Whitledge TE, MacIsaac JJ (1974) Spinup of the Baja California upwelling ecosystem. Limnol Oceanogr 19:553-572

- Weise MJ, Costa DP, Kudela RM (2006) Movement and diving behavior of male California sea lion Zalophus californianus during anomalous oceanographic conditions of 2005 compared to those of 2004. Geophys Res Lett 33:L22S10

> Wilkerson FP, Dugdale RC, Kudela RM, Chavez FP (2000) Biomass and productivity in Monterey Bay, California: contribution of the large phytoplankton. Deep Sea Res II 47:1003-1022

Submitted: November 26, 2007; Accepted: November 24, 2008 Proofs received from author(s): March 5, 2009 